NBER WORKING PAPER SERIES

\title{
WHY DO FIRMS BECOME WIDELY HELD? AN ANALYSIS OF THE DYNAMICS OF CORPORATE OWNERSHIP
}

\author{
Jean Helwege \\ Christo Pirinsky \\ René M. Stulz \\ Working Paper 11505 \\ http://www.nber.org/papers/w11505 \\ NATIONAL BUREAU OF ECONOMIC RESEARCH \\ 1050 Massachusetts Avenue \\ Cambridge, MA 02138 \\ June 2005
}

Stulz: Associate Professor, University of Arizona; Assistant Professor, Texas A\&M University; Reese Chair of Banking and Monetary Economics, Ohio State University, NBER and ECGI. We thank Bilal Ertruk and Carrie Pan for research assistance. We are grateful for comments from Rudi Fahlenbrach, Bernadette Minton, Ingrid Werner, Karen Wruck, and seminar participants at Ohio State. The views expressed herein are those of the author(s) and do not necessarily reflect the views of the National Bureau of Economic Research.

(C)2005 by Jean Helwege, Christo Pirinsky and René M. Stulz. All rights reserved. Short sections of text, not to exceed two paragraphs, may be quoted without explicit permission provided that full credit, including (C) notice, is given to the source. 
Why Do Firms Become Widely Held? An Analysis of the Dynamics of Corporate Ownership Jean Helwege, Christo Pirinsky and René M. Stulz

NBER Working Paper No. 11505

July 2005

JEL No. G30, G32, D0

\section{$\underline{\text { ABSTRACT }}$}

We consider IPO firms from 1970 to 2001 and examine the evolution of their insider ownership over time to understand better why and how U.S. firms that become widely held do so. In our sample, a majority of firms has insider ownership below $20 \%$ after ten years. We find that a firm's stock market performance and trading play an extremely important role in its insider ownership dynamics. Firms that experience large decreases in insider ownership and/or become widely held are firms with high valuations, good recent stock market performance, and liquid markets for their stocks. In contrast and surprisingly, variables suggested by agency theory have limited success in explaining the evolution of insider ownership.

Jean Helwege

Eller College of Management

The University of Arizona

1130 E. Helen Street

P.O. Box 210108

Tucson, AZ 85721-0108

helwege@eller.arizona.edu

Christo Pirinsky

Department of Finance

$306 \mathrm{H}$ Wehner Bldg.

4218 Texas A\&M University

College Station, TX 77843

cpirisnky@mays.tamu.edu
René M. Stulz

Fisher College of Business

Ohio State University

806A Fisher Hall

2100 Neil Avenue

Columbus, OH 43210-1144

and NBER

stulz@cob.osu.edu 


\section{Introduction}

Most firms start their life with concentrated ownership. Yet, the typical large established U.S. firm has fairly dispersed ownership. How do firms evolve so that many of them end up with dispersed ownership? Why does that evolution take place? There has been much recent research on the determinants of insider or managerial ownership. ${ }^{1}$ However, this research focuses on understanding why, at a point in time, insiders or managers own a larger fraction of shares in some firms than in others. The evolution of ownership as firms mature has not been the object of much study in the U.S. ${ }^{2}$ As a result, we know little about the dynamics of insider ownership following a firm's IPO. In this paper, we attempt to understand these dynamics better.

The stylized fact that large U.S. corporations are much more likely to have dispersed ownership than comparable corporations in most other countries (see La Porta, Lopez-de-Silanes, and Shleifer, 1999, LLS) plays a central role in much of modern corporate finance. In the U.S., observers since Berle and Means (1932) have been concerned that diffuse ownership facilitates entrenchment by managers and these concerns have led to a large literature on agency costs and governance. An intense controversy has evolved over the issue of whether firms in which managers own more shares perform better and have higher valuations (see Himmelberg, Hubbard, and Palia, 1999, Demsetz and Villalonga, 2001, and McConnell, Servaes, and Lins, 2005). Cross-country comparisons of corporate ownership raise the question of what it is that makes the U.S. and a few other countries unique in having dispersed ownership. Is it differences in politics, as argued by Roe (2003)? Or is it because of better legal protection of investors, as argued by LLS? A recent paper by Becht and de Long (2005) concludes with the statement: "We wish that we knew." Investigating the dynamics of ownership following a firm's IPO in the U.S. should help us understand better these issues.

\footnotetext{
${ }^{1}$ See, for instance, Demsetz and Villalonga (2001) and Himmelberg, Hubbard, and Palia (1999) for recent papers that make ownership structure endogenous.

${ }^{2}$ One paper that follows ownership beyond the years immediately following the IPO is Mikkelson, Partch, and Shah (1997). Their focus differs from ours. Though they document the evolution of insider ownership for firms with IPOs from 1980 through 1983 for the ten years following the IPO, they are mostly concerned about how ownership explains performance.
} 
We follow a large sample of firms over time to understand why and how their ownership becomes more dispersed following their IPO. Our database includes all firms that have an IPO from 1970 to 2001. We are able to follow the ownership of these firms from 1986 through 2001. LLS consider two definitions of widely held firms. With their first definition, a firm is widely held if there is no controlling blockholder who owns more than $20 \%$ of the votes. Rather than focusing on the largest blockholder, we consider the holdings of the officers and directors of the firm, whom we call insiders as is common practice, so that a firm meets the $20 \%$ standard when its insiders own less than $20 \%$ of the shares. We find with our dataset that insiders control less than $20 \%$ of the cash flow rights in half the firms ten years after their IPO. With this measure, therefore, the road to diffuse ownership is quick for the typical firm. The more restrictive definition of diffuse ownership used by LLS is that there is no controlling blockholder who owns more than $10 \%$ of the votes. Strikingly, insiders own less than $10 \%$ of the shares in roughly a quarter of the firms five years after their IPO. However, the $10 \%$ standard is one that is not met by the typical firm in our sample in any year within thirty years of its IPO. Because our sample drops in size over time, so that by thirty years, less than $3 \%$ of the IPO firms are still in the sample, it is difficult for us to evaluate when half the firms eventually meet this stricter standard.

Insider ownership is defined as the ratio of shares held by insiders over the total number of shares the firm has outstanding. Insider ownership can therefore fall because the numerator of the ratio falls or the denominator increases. Increases in the denominator take place when the firm issues shares to raise cash, to pay for acquisitions, to deliver shares upon exercise of stock options and warrants, and conversion of convertible debt. As long as the participation of insiders in equity issues is less than their proportional holdings of shares, their proportional ownership drops when new shares are issued.

In a study for the U.K., Franks, Mayer, and Rossi (2004) find that increases in the number of shares due to mergers play a central role in ownership dilution in the U.K. We find that the evolution of ownership in our sample is different: sales of shares by insiders are as important, on average, in explaining the decrease in insider ownership as issuance of new shares by the firm. Further, share issues 
in primary offerings and to pay for mergers constitute only a fraction of the increase in shares for our firms. This result could be at least partly explained by the importance of option compensation in the U.S. ${ }^{3}$

Insiders reduce their ownership of the firm when the costs of doing so are less than the benefit. The benefit is that insiders can diversify their portfolio and grow the firm faster because firm growth is less dependent on their co-investment. The costs are that the value of the shares falls if insiders control a smaller share of cash flows than the firm value maximizing ownership share. To the extent that insiders care about control separately from the value of their stake, a reduction in their proportional holdings also decreases their ability to influence the decisions of the firm and to resist takeovers. The literature has several theories that help understand why optimal holdings by insiders may fall as a firm matures so that it becomes worthwhile for insiders to reduce their fractional holdings of a firm's shares. These theories are not mutually exclusive, so that we would not be surprised to find some support for each, but we want to investigate whether some of these theories describe the data better than others.

The main ideas found in the literature can be summarized as follows:

1) Moral hazard. From Jensen and Meckling (1976) onward, agency theory predicts that ownership will be more concentrated when controlling insiders find it easier to take advantage of outside or minority shareholders. Corporate insiders have a multitude of ways to benefit from their control of the firm and make the stake of minority shareholders worth less. The literature has focused on shirking, perk consumption, investment choice, and tunneling as the main vehicles for insiders to benefit from their control position. ${ }^{4}$ As the ownership of insiders increases, their actions become better aligned with the interests of minority shareholders but they also bear more risk. With this agency view, we would expect firms to become widely held for two reasons. First, some types of agency problems

\footnotetext{
${ }^{3}$ See Fama and French (2005) for evidence that option exercises can substantially increase the number of shares outstanding.

${ }^{4}$ See, for instance, Shleifer and Vishny (1997).
} 
become less important. Second, new ways of managing agency problems become cost effective as the firm becomes larger. ${ }^{5}$

2) Adverse selection. Leland and Pyle (1977) model retention of shares by insiders as a signal of firm quality when information asymmetries are high. As shown by Myers and Majluf (1984), if insiders maximize the wealth of existing shareholders, they will choose to sell equity only if they can do so at an advantageous price. This adverse selection makes it expensive to sell shares when information asymmetries are important. Maug (2001) and Subrahmanyam and Titman (1999) point out that it becomes advantageous for firms to have outside shareholders, and hence to have more dispersed ownership, when information from outside the firm becomes more important to managers in making their decisions. With these models, more dispersed ownership becomes advantageous when the informational advantage of insiders becomes less important. We would therefore expect firms to become widely held when more is known about them and information asymmetries have become less important.

3) Timing. There are two strands of research in the literature that imply insiders would be concerned about the market for the firm's shares when they choose to increase the supply of shares available for trading, either through sales of their own shares or through issuance of new shares. First, a number of authors argue that it pays for firms to time the sale of new shares when they are advantageously priced (window of opportunity hypothesis). ${ }^{6}$ Since insiders decide when the firm sells shares, they can also time sales for their own account. The evidence of Clarke, Dunbar, and Kahle (2004) on secondary equity issues is consistent with the ability of insiders to gain from the timing of the sale of

\footnotetext{
${ }^{5}$ See Fama and Jensen (1983).

${ }^{6}$ See Baker and Wurgler (2002). Schultz (2003), Pastor and Veronesi (2005), and Benninga, Helmantel, and Sarig (2005) review the evidence for IPOs and provide models of timing that rely on the efficient market hypothesis. Baker and Stein (2004) review evidence for SEOs and propose a model of timing that does not rely on the efficient market hypothesis.
} 
their shares. Second, there is a literature claiming that the demand for shares can be downwardsloping, in which case making more shares available for trading would lead to a decrease in price. ${ }^{7}$ When the market for shares for a firm becomes deeper and more liquid, the demand for shares becomes more elastic, so that it becomes less costly for insiders to sell shares in the market. Empirical evidence shows that the cost of selling a block of shares for a small firm can be large. ${ }^{8}$

We investigate how the variables that are influential in these theories play a role in the evolution of insider ownership for firms and in the process whereby some firms become widely held and others not. We use two different approaches. First, we examine the determinants of significant decreases in insider ownership, where we define a significant decrease in insider ownership to be a decrease of at least $5 \%$. Second, we estimate a hazard rate model of becoming widely held. We estimate this model for the two definitions of widely-held firms used by LLS.

We find that stock market variables play an extremely important role in the process that leads firms to become widely held. First, firms with greater stock market turnover are more likely to see the ownership share of insiders fall and are more likely to become widely held. Second, firms with high book-to-market ratios are less likely to see an increase in ownership dispersion. Third, the likelihood that insiders will decrease their ownership share significantly increases with the firm's recent stock market performance. Hence, firms move towards dispersed ownership when the market for their shares is liquid in the sense that a large block of shares can be sold without too much of a discount. Strikingly, the moral hazard and information asymmetry variables seem to be largely irrelevant in predicting large changes in insider ownership. This is even more so in a regression where we use lagged changes for most of the explanatory variables. In that regression, ownership is expected to decrease significantly when it is high and when the stock has performed well.

\footnotetext{
${ }^{7}$ Bagwell (1991) reviews the literature and discusses the implications of downward-sloping demand curves for corporate finance. The more recent literature combines diversity of opinion with limits of arbitrage. See, for instance, Baker, Coval, and Stein (2005) for a model and a review of the evidence.

${ }^{8}$ See Keim and Madhavan (1996), for instance.
} 
The moral hazard and information asymmetry variables are slightly more informative in the hazard models that predict whether a firm is likely to become widely held in a particular year. The hazard models predict that firms are more likely to meet the $10 \%$ threshold in a given year after not having met it if they have VC financing, are large, have a low book-to-market ratio, have low cash flow, report $\mathrm{R} \& \mathrm{D}$ expenditures, have low leverage, have low volatility, have high lagged and contemporaneous stock returns, and have high turnover. Stock return volatility is often used as a proxy for information asymmetries and agency problems, but high stock return volatility also makes it costly for insiders to have a large stake. Our evidence suggests that the latter effect is less important than the former. We would expect R\&D to make it less likely that a firm becomes widely held, so that its coefficient in the hazard model is surprising. We find no evidence that firms with more hard assets are more likely to become widely held, which seems inconsistent with the moral hazard and information asymmetry theories.

The paper proceeds as follows. In Section 2, we present our database. We explain its construction and provide summary statistics for cohorts of IPO firms. In Section 3, we investigate the evolution of inside ownership and the time it takes for firms to become widely-held in our sample using the definitions from LLS. In Section 4, we examine the determinants of large changes in ownership. We also show how these changes take place. In Section 5, we provide estimates of hazard models of firms going from being concentrated to being widely held. We conclude in Section 6.

\section{Data}

Our analysis involves tracking the evolution of firms' insider ownership as they mature. This exercise is more sensibly done using firms' data from the time of the IPO onward, given that it is quite difficult for the insiders to sell shares in any major way while the firm is still private. ${ }^{9}$ We identify IPOs using data from 1970 through 2001 provided by Securities Data Corporation (SDC). We include only common

\footnotetext{
${ }^{9}$ This is particularly true if we count venture capitalists as insiders, which is highly likely given that they often hold a seat on the board of directors.
} 
stock offerings and we eliminate any IPOs in SDC that are flagged as reverse LBOs, spinoffs, rights offerings, or unit offerings. This process leaves us with 9,057 IPOs.

SDC data on IPOs are matched with CRSP using 6-digit cusips. Based on SIC codes reported in CRSP, we also exclude regulated utilities (SIC codes 4900-4949) and financial institutions (SIC codes in the 6000 range), on the assumption that the relation between fundamental characteristics and firm ownership differ for these firms because of regulatory constraints. ${ }^{10}$ In cases where trading prices are available on CRSP prior to the IPO date reported by SDC, we exclude the firm, on the assumption that the IPO information is incorrect. Because our sample dates to 1970 and includes many NASDAQ firms, we allow a firm to be in the data even if its first price in CRSP is substantially after the IPO. Otherwise, CRSP coverage of NASDAQ firms, which begins in 1972, would greatly reduce the sample. This procedure yields a total 6,319 IPO firms. We match SDC data to CRSP daily and monthly returns data and use CRSP to obtain data on prices, returns, share volume, and shares outstanding.

We obtain data on insider ownership from Compact Disclosure, which is a CD-Rom product that is produced each month. Compact Disclosure attempts to provide information on all firms that file with the SEC and have assets in excess of $\$ 5$ million. Because the differential information in each CD-Rom from one month to the next is fairly small and we do not have access to all the CDs, we only use the October CDs to produce the dataset. We have October CDs available from 1987 to $2002 .{ }^{11}$ Compact Disclosure contains text versions of SEC filings and has the ability to create summary reports of many variables. The main variable of interest for our analysis is the ratio of insiders' holdings of common shares over total shares outstanding (obtained from CRSP). Insiders are defined as officers and directors of the firm in Compact Disclosure. Our insider ownership variable is therefore the same as the one used, for instance, in Himmelberg, Hubbard, and Palia (1999). Obviously, our ownership data is only as good as the proxy

\footnotetext{
${ }^{10}$ See Demsetz and Lehn (1985) for evidence of the importance of regulation for corporate ownership.

${ }^{11}$ For 1988 and 1995, we sample ownership in November instead of in October, and for 1987 we use the CD from January 1988.
} 
data reported to the SEC. The proxy data may lead us to understate inside ownership if insiders disavow blocks they effectively control.

Researchers have compared ownership data from Compact Disclosure to ownership data from other data sources as well as from proxies. Anderson and Lee (1997) find that Corporate Text dominates Compact Disclosure as a data source, but these two data sources are better than Spectrum or Value Line. The disadvantage of Corporate Text for our study is that it covers primarily NYSE and AMEX firms before 1995 and is therefore unsuitable for our sample, in which NYSE-listed firms represent only 15\% of our firm-years. Anderson and Lee (1997) conclude that the advantage of Corporate Text over Compact Disclosure is due to a significant extent to firms with dual class shares. In the reported results, we use firms with dual class shares. We investigate whether our results are affected by these firms. As Gompers, Ishii, and Metrick (2004) point out, there is no easy way to identify dual-class firms. To identify these firms in our sample, we follow their method and classify as dual-class firms those firms that have multiple CUSIP numbers that differ in their $7^{\text {th }}$ and $8^{\text {th }}$ digits. ${ }^{12}$ Our sample includes $5.94 \%$ of firm-year observations from firms that have dual class shares according to this criterion. We estimate our regressions without these firms and find that our results are not affected by them. While Anderson and Lee (1997) use a panel of firms for 1992, McConnell, Servaes, and Lins (2005) compare ownership from Compact Disclosure to ownership obtained directly from proxies for a sample of 200 randomly selected firms from 1992 through 1997. They find that the correlation coefficient between the two ownership sources is 0.92 .

Compact Disclosure reports the number of shares held by insiders as of a certain date and it also reports shares outstanding, but the latter is often as of another date. When Compact Disclosure reports the proxy date, we obtain the total number of shares from CRSP for the same month as the date of the

\footnotetext{
${ }^{12}$ They use two additional criteria. One uses new issues from SDC and the other uses information from the Investor Responsibility Research Center (IRRC).
} 
proxy. If Compact Disclosure reports more than one proxy date, we take the latest date reported. ${ }^{13}$ For example, if a CD-Rom dated October 1993 has two proxy filings, one from March 1993 and another from March 1992, as well as a 10-K from June 1993, we assume the ownership data are as of March 1993. Since for a typical (October) $\mathrm{CD}$, the latest proxy date is either from the beginning of the corresponding year or from December of the previous year, we assign the ownership information to the previous calendar year. In the above example, we assume that ownership for the 1992 calendar year is given by the data of March 1993. ${ }^{14}$

Our sample of insider ownership data spans the years 1986-2001. Consequently, we are able to track ownership from 1986 onward. The insider ownership of a firm that had an IPO in 1972 would therefore be tracked from 1986. For some firms we can track ownership from the time of the IPO onward for more than a decade. For other firms, the first year of ownership data may be up to 16 years after the IPO.

Compact Disclosure is matched to CRSP using 6-digit cusips. Once the ownership data and CRSP are matched, we match this data to the IPO data via cusips. Our final sample contains 5,281 firms for which at least one year of Compustat data and ownership data are available.

Table 1 provides information on our sample for different IPO years. Not surprisingly, the number of IPOs varies sharply over time. We have a large number of IPOs in the first few years of the sample period, but then there is a dramatic lull in the IPO market until the early 1980s. The market slows down towards the late 1980s before rebounding again in the early 1990s. It slows down sharply at the end of our sample period. For the IPOs before 1986, we lose a large number of observations when we require CRSP data and then many more observations when we merge with Compact Disclosure. The latter is mostly due to the fact many IPO firms from the 1970s and early 1980s do not survive until 1986, the first

\footnotetext{
${ }^{13}$ This matching procedure results in insiders owning more than $100 \%$ of the shares for 549 firm-years out of 27,512 firm-years. We eliminate these cases in our analysis.

${ }^{14}$ If Compact Disclosure doesn't report a proxy date for a particular firm but it reports insider ownership for that firm, we compute the insider ownership share as the ratio of the number of shares held by insiders over the number of shares outstanding at the end of the previous year. For instance, if the October 1993 CR-Rom reports insider ownership without a proxy date, we divide insider ownership by shares outstanding at the end of 1992 and use that ratio as our insider ownership measure for 1992.
} 
year with information about insider ownership. As a result, for the 1970s, we lose more than threequarters of the IPO firms. After 1986, we still lose a substantial number of firms when we merge with CRSP and drop utilities and financial firms, but merging with Compact Disclosure has a minimal impact on sample size.

We use data from SDC to determine if an IPO is venture-backed. SDC is also the source of data on seasoned equity offerings (SEOs) and mergers (especially those involving stock swaps). We also rely on daily data in CRSP to obtain estimates of idiosyncratic volatility from market model regressions, the exchange on which the firm is listed, and for calculating the daily turnover of the NYSE firms and of the Nasdaq firms. All remaining data are obtained from Compustat.

\section{When do firms become widely held?}

In this section, we investigate the path to dispersed ownership for the firms in our sample. We conduct our investigation using two different samples: the continuous ownership data sample and the whole sample. The continuous sample includes firms with continuous ownership data from the IPO to the year when they have their first missing observation or the year when they first become widely held. ${ }^{15}$ By construction, this sample includes firms with IPOs from 1986 onward. Though many of our results use only the continuous sample, we also report some results that use all our firms, including firms that had their IPO between 1970 and 1985 and for which ownership data is available only after 1985. This sample (we call it the whole sample) uses data from any IPO firm that has data on Compustat, CRSP, and Compact Disclosure. The benefit of using the whole sample is that it allows us to track ownership of firms up to 31 years after their IPO. In contrast, a firm in the continuous sample can be tracked no more than 16 years from its IPO.

Figure 1 shows the distribution of insider ownership changes for firms in the whole sample. It is immediately obvious that many more changes in ownership are negative than positive. The mean change

\footnotetext{
${ }^{15} \mathrm{We}$ also use a sample where we add firms to the continuous sample that have gaps in their data not exceeding two years. Our results also hold for this sample.
} 
in ownership is $-2.07 \%$ per firm-year and the median is $-0.30 \%$. Both figures are statistically different from zero. The distribution is only slightly skewed to the left (the skewness is -0.37) and has high kurtosis (14.52).

Table 2 also uses the whole sample. It provides statistics on insider ownership in event time starting with the first year following the IPO. For instance, we find that in year 5 after the IPO the median insider ownership is $21.11 \%$. It is interesting to note that the comparable figure for that year reported by Mikkelson, Partch, and Shah (1997) is $28.6 \%$, substantially higher than our estimate, but their median ownership after 10 years is $17.9 \%$, which is very close to our estimate of $18.33 \%$. Our estimate is based on a sample with roughly 15 times as many observations as their sample of IPOs from 1980 through 1983. Another useful benchmark for our ownership data is the work of Holderness, Krozner, and Sheehan (1999). They examine insider ownership across 4,200 exchange-listed firms in 1995 . They find that average insider holdings are $21 \%$ and median insider holdings are $14 \%$. Consequently, the average and median insider holdings of our IPO firms match the average and median of the population after 25 years. Viewed from this perspective, it takes a long time for the ownership of IPO firms to look like the ownership of the population of firms.

Average insider ownership is $38.22 \%$ at the end of the first year after the IPO and falls steadily over time, nearly dropping in half over thirty years. However, the sample size falls sharply over time. While we have 3,878 firms in year 1 , we end up having only 70 firms in year 30 . The second column provides the $25^{\text {th }}$ percentile of the distribution. We see that by year 5, a quarter of the sample's ownership level is below the $10 \%$ threshold. The level of ownership for this percentile drops by almost three quarters over thirty years. The median holdings fall more quickly than the mean holdings, indicating that the distribution of ownership is skewed to the right. The $75^{\text {th }}$ percentile falls less sharply than the $25^{\text {th }}$ percentile, since it drops by less than half over thirty years.

LLS call firms widely held if the controlling shareholder controls less than $10 \%$ of the votes with one threshold or less than $20 \%$ of the votes with the other. Our ownership measure is slightly different since 
we focus on ownership of cash flow rights by insiders. We follow their approach and compute the fraction of firms where insiders own less than $10 \%$ of cash flow rights (WH10) and the fraction of firms where they hold less than $20 \%$ (WH20). We find that only one firm in 8 meets the $10 \%$ standard and slightly more than one firm in 5 meets the $20 \%$ standard at the end of the year after the IPO. This shows that using these thresholds it is infrequent for a firm to be widely held shortly after its IPO. However, the fraction of firms that are widely held grows steadily. With the $20 \%$ standard, the median firm is widely held shortly before year 10 . For the $10 \%$ standard, it takes much longer for the median firm to be widely held. In fact, after 30 years, the median firm is not widely held, but after that the number of firms in our sample becomes quite small and hence not useful to reach robust conclusions. It follows from Table 2 that firms become widely held fairly quickly on average using a $20 \%$ standard, but not using a $10 \%$ standard. In light of the results of Holderness, Krozner, and Sheehan (1999), this may not be surprising since median firm ownership is higher than $10 \%$ in their sample of 1995 firms. Nevertheless, close to one third of firms are widely held after the tenth year following their IPO using the $10 \%$ standard.

Figure 2 provides another way to look at how firms become widely held over time. In that figure, we use the continuous sample to show the change in insider ownership over time relative to ownership at the time of the IPO. We exclude all firms that were widely held at the time of the IPO relative to the $10 \%$ threshold, as they are unlikely to exhibit much change in inside ownership. The figure also shows that the change in insider ownership is much larger in earlier years following the IPO than later. When we split the sample period for the continuous sample into two subperiods of similar length, we find similar results for both subperiods.

Another useful way to look at the data is to ask the question of how likely it is for a firm with concentrated ownership entering year $n$ after its IPO to become widely held in that year. Table 3 provides estimates of such conditional probabilities. The Table includes only firms in the continuous sample as the whole sample includes firms that might become widely held in the year or years for which we have no 
data. With this sample, the number of firms that could become widely held after year 10 is less than 100 for each threshold.

The probability of becoming widely held at the $10 \%$ threshold is $10 \%$ or higher in only three years. In contrast, the probability of becoming widely held at the $20 \%$ threshold is $10 \%$ or higher in most years. This reflects the fact that a firm is much more likely to meet the $20 \%$ threshold than the $10 \%$ threshold. There is no evidence that the probability of becoming widely held decreases monotonically over time, but the highest probability is in year 1 for both thresholds. We see that each year we lose firms from our sample. Except for the early years, we typically lose more firms than there are firms becoming widely held.

\section{How do large changes in the ownership share of insiders take place?}

In this section, we investigate the nature of large inside ownership changes and the determinants of such changes. As noted by Zhou (2001), insider ownership typically does not change much from year to year. In our data, the mode of the distribution of changes is $0 \%$. To understand changes in the ownership share of insiders, we therefore analyze how significant changes in ownership take place and firm characteristics that are correlated with such changes. We define a significant change in ownership as a reduction in the ownership share of insiders of $5 \%$ of the firm's equity or more. We use $5 \%$ because it corresponds to the regulatory threshold for the definition of a block holding (Rule 13d-1(a) of the Securities Exchange Act). So, a drop in the ownership share of insiders from $40 \%$ to $33 \%$ would correspond to a significant reduction in insider ownership but a drop from $40 \%$ to $37 \%$ would not.

The ownership share of insiders can change because the number of shares held by insiders falls and/or because the number of shares outstanding for the corporation increases. To account for the changes due to each factor, we use the following decomposition of the change in the ownership share of insiders. Define $\Delta \alpha_{t}$ to be the change in the ownership share of insiders from $t$ to $t+1, S_{t}$ to be the number of shares held by 
insiders at date $t$, and $\mathrm{N}_{\mathrm{t}}$ the firm's number of outstanding shares at date $\mathrm{t}$. The ownership share of insiders at $t, \alpha_{t}$, is equal to $S_{t} / N_{t}$. With this notation, we have:

$$
\begin{aligned}
& \Delta \alpha_{t}=\left(\frac{S_{t+1}}{N_{t+1}}\right)-\left(\frac{S_{t}}{N_{t}}\right)=\frac{S_{t+1}}{N_{t+1}}-\frac{S_{t+1}-\Delta S}{N_{t}}=\frac{\Delta S}{N_{t}}+\frac{S_{t+1}}{N_{t+1}}-\frac{S_{t+1}}{N_{t}} \\
& =\frac{\Delta S}{N_{t}}+\frac{S_{t+1} N_{t}}{N_{t+1} N_{t}}-\frac{S_{t+1} N_{t+1}}{N_{t} N_{t+1}}=\frac{\Delta S}{N_{t}}-\frac{S_{t+1} \Delta N}{N_{t+1} N_{t}} \\
& =\frac{\Delta S}{N_{t}}-\alpha_{t+1} \frac{\Delta N}{N_{t}}
\end{aligned}
$$

The first term in the last line of equation (1) is the change in $\alpha$ explained by changes in the number of shares held by insiders (the numerator of the fractional ownership formula). The second term is the change in inside ownership brought about by a change in the number of shares outstanding (the denominator of the fractional ownership formula).

We use equation (1) to understand better how ownership changes. Table 4 shows the distribution of significant changes in the ownership share of insiders. We find that both the average and median changes in insider ownership are large in years in which insider ownership decreases by at least $5 \%$. In particular, the mean decrease is $15 \%$. Using our decomposition, we find that on average the change in insider ownership due to sales by insiders is slightly higher than the change in insider ownership due to the increase in the number of shares. The number of shares outstanding can increase because of a variety of reasons. For instance, it increases when the firm issues shares, when it pays for a merger with shares, and when executives exercise stock options. It follows, therefore, that mergers are a less important contributor to the reduction of the insider ownership share than sales of shares by insiders. This result contrasts sharply with the conclusion of Franks, Mayer, and Rossi (2004) for the U.K. The relative importance of sales by insiders is greater when we consider medians.

We also collect information on secondary offerings from SDC. These are likely to be sales of stock by the insiders in a public offering, although they could be sales by blockholders who do not have a seat 
on the board of directors. To be conservative, we use secondary offerings for the three-year window centered on the year of significant insider ownership change. This window ensures that we include all secondary offerings that could possibly be related to the change in insider ownership. Using a three-year window provides an upper-bound to the change in ownership that can be accounted for by secondary offerings. We find that secondary offerings account for a small fraction of the change in inside ownership on average.

To consider more directly the role of share issues and the reason for such issues, we investigate the change in shares outstanding brought about by equity issues and mergers around the years in which insider ownership changes by more than $5 \%$. We again use a three-year window. We find that shares issued through SEOs and mergers represent a small fraction of the increase in shares. This result is surprising. An obvious worry is that SDC does not record some of the seasoned issues and mergers of the firms in our sample because these firms are too small for their transactions to be noticed. Thus, we investigate whether the results are different if we split our sample into large and small firms. We find that Table 4 is very similar if we only include the large firms in our sample. It seems, therefore, that a more likely explanation for our results on SEOs and mergers is that options, private equity placements, and convertible conversions play an important role for firms that have recently completed their IPO.

\section{Why do firms have large changes in ownership?}

We now consider why firms have large changes in insider ownership that bring them closer to being widely held. Is it because of changes in optimal insider ownership that are consistent with the moral hazard and information asymmetry theories discussed in the introduction or because of windows of opportunity that enable insiders to sell shares and firms to issue shares at prices they find advantageous? In this section, we estimate probit regressions where the dependent variable takes value one if the firm experiences a decrease in insider ownership of at least $5 \%$ during a period. Therefore, the coefficient on a variable that makes it more likely that a firm experiences such an insider ownership decrease should be 
positive. Note that our regressions include lagged insider ownership as an explanatory variable, so that we are examining the relation between the explanatory variables and the probability of a large decrease in insider ownership conditional on a given level of insider ownership. The sample uses any IPO firm with data on Compustat, CRSP, and Compact Disclosure that is not widely-held at the beginning of the year using the $10 \%$ threshold.

The variables that the theories deem important and the proxies we use for them are as follows:

1. Level of insider ownership. If it is costly for insiders to bear firm risk, they are more likely to decrease their holdings if their holdings are large. We therefore expect a positive coefficient on this variable.

2. Venture capital. VCs typically hold a seat on the board of directors (Baker and Gompers, 2003), which means they are classified as insiders according to our data source, Compact Disclosure. Given that VCs aggressively cash out within a few years of the IPO (Field and Hanka, 2001), IPOs with VC backing would be more likely to experience substantial decreases in insider ownership. We expect a positive coefficient on this variable.

3. Firm size. We expect larger firms to have fewer information asymmetries. The relation between size and moral hazard is unclear. Larger firms are more monitored by institutional shareholders, analysts, the press, and regulators. However, they are less likely to be taken over and atomistic shareholders find coordination costs prohibitive. We use two size proxies. First, we use the logarithm of total assets. Second, we use a dummy variable if a firm has market value of equity greater than the $25^{\text {th }}$ percentile of NYSE firm. The dummy variable is used to capture a potential threshold effect where firms become more monitored as they stop belonging to the "small-firm" asset class.

4. Book-to-market ratio. Lower book-to-market ratio firms have more intangibles, so that the information asymmetry theories would predict that such firms should have higher insider 
ownership. A low ratio could indicate that the firm has high growth opportunities. High growth opportunities suggest more discretion on the part of management, which would lead to higher optimal insider holdings, but might also correspond to greater alignment of incentives between insiders and outside shareholders if insiders are empire-builders, which would lead to lower optimal insider holdings (see Stulz, 1990). Finally, window of opportunity theories would predict that firms are more likely to become diffusely held when their valuation is high.

5. Hard assets. We use the ratio of property, plant and equipment to total assets as our measure of hard assets. There is less scope for discretionary spending in firms with more hard assets (Gertler and Hubbard, 1993). Moral hazard theories therefore predict a positive coefficient on our proxy for hard assets.

6. Funding needs. Firms with less operating cash flow and more capital expenditures have greater funding needs, so that we would expect insider ownership to drop. Otherwise, if insider ownership is maintained constant, the firm is restricted in its ability to raise equity by the wealth constraints of the insiders. Further, Jensen (1986) expects higher agency costs for firms with higher free cash flow for given insider ownership. We therefore expect optimal insider ownership to be higher with higher free cash flow, so that the coefficient on free cash flow is expected to be negative both because of moral hazard considerations and because of funding considerations. We use EBITDA as our cash flow measure. For given investment opportunities, an increase in EBITDA corresponds to an increase in free cash flow.

7. Capital expenditures. Free cash flow falls with capital expenditures, so that we would expect firms with higher capital expenditures to be more likely to raise equity and see their insider ownership fall. Yet, greater capital expenditures mean more discretion for insiders, so that greater ownership would be required to insure that this discretion is used to benefit 
shareholders. This tension makes the sign of the coefficient on capital expenditures undetermined.

8. R\&D spending. $R \& D$ spending differs from other capital expenditures in that it is associated with more managerial discretion and greater information asymmetries. Firms with R\&D spending therefore should have higher optimal insider ownership (see Crutchley and Hansen, 1989, and Himmelberg, Hubbard, and Palia, 1999). We follow Himmelberg, Hubbard, and Palia (1999) and use a dummy variable for firms that report R\&D spending and a level variable which is $R \& D$ spending divided by total assets. We therefore expect a negative coefficient on a dummy variable that takes value one for firms that report R\&D spending and a negative coefficient on the level variable.

9. Dividends. Dividends reduce the intensity of agency problems by leaving fewer resources under the discretion of management and reduce information asymmetries through signaling. We therefore expect dividend payers to have lower optimal insider holdings and hence the coefficient on a dummy variable that takes value one if a firm pays dividends to be negative.

10. Leverage. Leverage controls agency problems (see Jensen, 1986, and Stulz, 1990) so that we expect more highly levered firms to be more diffusely held in equilibrium. Further, firms with high leverage are more likely to be firms that have too much debt, so that we would expect them to issue equity. As they issue equity, insider ownership falls, so that these considerations suggest a negative coefficient on leverage. However, if insiders are concerned about control, they will choose high leverage precisely so that they can afford a large proportional stake in the firm's cash flows, leading to a positive association between leverage and ownership (see Stulz, 1988).

11. Volatility. Volatility reduces the expected utility of insiders for a given stake in their firm, so that it makes them more likely to sell. However, volatility should also make them less likely to sell since information asymmetries are more important with greater volatility. Some 
authors also use volatility as a proxy for diversity of opinion and we would expect firms to be less likely to increase their float if diversity of opinion is higher. ${ }^{16}$ It follows that the coefficient on volatility is ambiguous. However, if information asymmetries can be neglected, the coefficient on volatility is unambiguously negative. We use the volatility of the residual of a one-year market model regression as our measure of volatility.

12. Turnover. Turnover is often used as a proxy for liquidity. Greater turnover means that the market for shares is deeper, so that sales by insiders have less of a price impact and insiders are more likely to sell shares. ${ }^{17}$ Because volume is measured differently on Nasdaq and on the NYSE, we use separate turnover variables for Nasdaq firms and NYSE firms. ${ }^{18}$ Note that Nasdaq-listed firms represent $86 \%$ of the firm-year observations in our sample.

13. Past and contemporaneous returns. Greater past returns mean that the firm has performed well, so that moral hazard considerations imply lower equilibrium insider holdings because insiders have built a reputation. Further, high past performance is associated with a deeper market for a firm's stock. ${ }^{19}$ Individuals are generally contrarian investors. ${ }^{20}$ We would therefore expect insiders who do not act on the behalf of institutions to be more likely to sell following high returns.

Table 5 compares firm characteristics at the end of year t-1 (except for contemporaneous returns) for the firms that experience a decrease in insider ownership of more than 5\% in year $t$ with those that do not. Strikingly, most differences are significant. Since means can be influenced by outliers, we pay more attention to medians. As predicted, we find that firms that experience large decreases in insider ownership

\footnotetext{
${ }^{16}$ See Moeller, Schlingemann, and Stulz (2005) and Baker, Coval, and Stein (2005).

${ }^{17}$ Turnover is sometimes used as a proxy for differences of opinion or information asymmetries (see, for instance, Dierkens, 1991, and Chen, Hong, and Stein, 2001). These considerations would predict a negative coefficient on turnover.

${ }^{18}$ See Atkins and Dyl (1997).

${ }^{19}$ See Chordia, Huh, and Subrahmanyam (2004).

${ }^{20}$ See, for instance, Kaniel, Saar, and Titman (2004) and the references therein.
} 
in a given year have more insider ownership the year before, a lower book to market ratio, higher turnover, and higher contemporaneous and past returns. ${ }^{21}$ The difference in contemporaneous and past returns is particularly striking since the firms with significant changes outperform those without such changes by more than ten percent in the current year and in the previous year. Firms experiencing large decreases in firm ownership are smaller when size is measured by the book value of assets than other firms. This is most likely due to the fact that larger firms have lower insider ownership to start with. Further, the firms that decrease ownership have a lower ratio of property, plant, and equipment to assets, greater volatility, lower leverage, are more likely to report R\&D expenses, have higher R\&D expenses, and are less likely to pay dividends. The univariate comparisons show that capital market variables have the predicted effects, but the comparisons for firm fundamentals do not always correspond to the predictions. The explanation for the mixed results for the comparisons of the fundamental characteristics could be that correlations among these characteristics obscure their true relationship with the probability of significant changes in ownership. We therefore turn to multiple regressions to examine whether that is the case.

Table 6 estimates probit regressions to investigate the impact of these variables on the probability of firms experiencing sizeable changes in insider ownership. We define a sizeable insider change to be one where insider ownership falls by $5 \%$ or more for a firm with insider ownership in excess of $10 \%$ at the beginning of the year. When considering whether a drop in insider ownership of $5 \%$ or more takes place in the t-th year following the IPO, all our explanatory variables are from year t-1 except for contemporaneous firm, industry, and market returns. The other explanatory variables could be directly affected in year $t$ by the change in ownership. This seems impossible for industry and market returns and the existence of a direct impact on calendar-year firm returns is questionable. It seems reasonable therefore to consider our explanatory variables to be predetermined rather than determined jointly with the change in ownership. The first regression is a pooled regression that uses all firm-years. The next five

\footnotetext{
${ }^{21}$ Note that the raw sample has firms with negative book-to-market, but these firms drop out as we impose our various data requirements so that they are not in the sample used to estimate our regressions.
} 
regressions are regression estimates for each year for the first five years following the IPO. The last regression uses all firm-years for firms past the fifth year from their IPO. The regressions for the subsamples allow the explanatory variables to affect the probability of large changes in insider ownership differently depending on the level of maturity of the firm.

We find that firms with larger insider ownership and firms with venture capital investors are more likely to experience a large drop in insider ownership as predicted. Firm size predicts larger drops in insider ownership, but this effect seems restricted to the early years only. The dummy variable is never significant. Book-to-market always has a negative coefficient which is significant in all years but year 5 . Property, plant, and equipment is significantly negative in one regression and significantly positive in another. Our cash flow measure has a negative coefficient in all regressions, so that insiders not pushed by financing needs are less likely to sell shares. Alternatively, it could be that firms with high cash flow have more agency problems as in Jensen (1986). However, it seems that the ability to generate cash plays a more important role than the demand for cash to invest. Capital expenditures do not affect the probability of large decreases in insider ownership. The coefficient on R\&D expenditures is positive and significant in five regressions, while the dummy variable for firms that report R\&D is significantly negative in two regressions. Leverage is significantly negative in one regression and significantly positive in another. Volatility is significant and positive in year one, but in no other year. Turnover for NYSE firms is significant in the pooled regression and in one other regression, whereas turnover for Nasdaq firms is significant in all regressions but one. Finally, turning to returns, the firm's return is always positive and significant and the lagged return is positive and significant in every regression but one. The contemporaneous industry return is also positive and significant, but the lagged industry return is almost never significant. The market return mostly does not seem to affect the probability of large decreases in ownership, though the coefficient in the pooled regression is positive and significant for the contemporaneous market return. 
The evidence presented in Table 6 indicates that the initial level of insider ownership, funding needs, book-to-market, turnover, and contemporaneous and lagged firm returns are the main drivers of large decreases in insider ownership. The other variables, which play a role in the moral hazard and information asymmetry theories, are generally not significant. The message is very much that insider ownership falls when the shares trade at a high price relative to the book value of their assets and relative to their past value, and when the market for the shares is more liquid. The variables emphasized by the moral hazard and information asymmetry theories seem of second-order importance.

There is a large literature in finance which relates Tobin's q to managerial ownership. ${ }^{22}$ Tobin's q is closely related to the inverse of book-to-market. This literature often focuses on the existence of a nonlinear relation between $\mathrm{q}$ and managerial ownership where an increase in managerial ownership leads to a higher q at least for low levels of managerial ownership. There is a great deal of debate as to whether $\mathrm{q}$ is high because insider ownership is high or whether a high $\mathrm{q}$ is associated with higher optimal insider ownership. Tobin's q is negatively related to the book-to-market coefficient. In this paper, we therefore add a different consideration, namely that a high $\mathrm{q}$ leads to a subsequent decrease in managerial ownership. At least for firms close to their IPO, this result seems difficult to square with the argument that a high q leads to a high optimal amount of insider ownership.

In Table 6, a firm's explanatory variables reflect past cumulative changes in these variables. In table 7, we use instead the lagged change in these variables (i.e., the change from t-2 to t-1) with two exceptions. First, returns are flow variables already, so it would make no sense to difference them. Second, we keep the level of insider ownership to investigate whether a high level predicts a decrease in insider ownership. We do the same for the $\mathrm{VC}$ variable. By using lagged changes, we lose the regression for year 1 that we were able to estimate in Table 6 . The only variables that are consistently significant are the level of insider ownership, firm returns, and lagged firms returns, and contemporaneous industry returns. The higher a firm's insider holdings, the more likely the firm is to experience a large drop in

\footnotetext{
${ }^{22}$ See Demsetz and Villalonga (2001) for a review of this literature.
} 
insider holdings. As before, firms are more likely to experience a large drop in insider holdings if they perform well. None of the variables that proxy for moral hazard problems or information asymmetries are consistently significant. The pooled regression that uses the whole sample has mixed results. Increases in $R \& D$ expenses make it more likely that a firm will experience a large drop in insider ownership in contrast to agency theory predictions, but an increase in plant, property, and equipment also makes such a drop more likely in conformity with these predictions. Overall, the regressions seem therefore most consistently supportive of windows of opportunity theories. However, surprisingly, changes in turnover are not significant.

We explored the robustness of our conclusions by changing the explanatory variables in our regressions. We were concerned that market variables are correlated with variables that are important for the moral hazard and information asymmetry theories. We therefore re-estimated our regressions without any of the market variables. Doing so had no impact on our conclusions. The regressions we report have neither time nor industry dummies. We added such dummies, but doing so had no impact on our conclusions because these dummies are generally not significant. Finally, we estimated the regressions using only one size variable and one R\&D variable. Doing so does not affect our conclusions.

\section{Estimating the conditional probability that a firm will become widely-held}

In the previous section, we studied the probability that insiders in a firm would decrease their proportional holdings substantially. We saw that the evidence is mostly supportive of theories that emphasize capital market considerations. Insiders sell when they get a good price and the market for the stock is good, causing insider ownership to fall over time. In this section, we focus on the probability that a firm becomes widely held in one year given that it was not widely held the year before. To study this issue, we estimate a hazard model.

A hazard function is similar to a logit function in that it estimates the probability of an event occurring. In our case, we consider the event of becoming widely held, where we define widely held as 
having less than $10 \%$ insider ownership (or, alternatively less than $20 \%$ insider ownership). A hazard function differs from a logit in that it combines multiple periods together in one estimation procedure. Moreover, the estimation procedure focuses on the conditional probability of becoming widely held (i.e., given that the firm was not widely held last period, what is the probability it will be this period?). Hazard functions have been used in a variety of applications in finance, such as estimating the probability of bank failure, prepayment of residential mortgages, predicting bankruptcy or default, and of a firm starting an ADR program. ${ }^{23}$

One can apply a variety of different hazard function models to estimate the conditional probability of becoming widely held. We apply the proportional hazard function of Cox (1975), which is a semiparametric approach that does not specify the parameters of the baseline hazard function. Rather, the approach of a proportional hazard model is to estimate the covariates that shift a baseline hazard function up or down. If a covariate has a significant positive coefficient, it means firms with above average values of that factor are more likely to become diffusely held. Likewise, a significant negative coefficient implies a downward shift of the baseline hazard function, or a lower probability of becoming widely held.

One receives a sense of the baseline hazard function from the data presented in Table 3. In fact, the probabilities in Table 3 constitute what is known as the Kaplan-Meier estimate of the hazard function, which is considered a good approximation of the baseline hazard. The idea of the Kaplan-Meier estimate is to report the conditional probability of an event occurring in each interval, where the probability is conditional on having survived up to the beginning of the interval. In the case of the Kaplan-Meier estimator, the probability is approximated by the frequency of events. In our case, it is the fraction of firms that become widely held during the interval, conditional on not having been widely held before.

An important aspect of this calculation involves the use of data from firms that do not provide complete data. Suppose we observe a firm's inside ownership from the year of the IPO and each year

\footnotetext{
${ }^{23}$ See Lane, Looney and Wansley (1986), Whalen (1991) and Helwege (1996), Schwartz and Torous (1993), McDonald and Van de Gucht (1999), Shumway (2001), and Doidge, Karolyi, Lins, Miller, and Stulz (2005).
} 
thereafter for five years. This firm is not widely held at any point while we have data for it and we cease to observe its insider holdings after five years. This is an example of a censored observation. Censored observations contribute to the estimation by being included in the group of firms at risk of becoming widely held. Table 3 shows the number of firms at risk of being widely held at the beginning of the year (but are not yet widely held), including firms that may not be observed two or ten years later. In order for this step to be considered proper in the estimation of a hazard function, we must have confidence that the censored observations are randomly missing. For example, we would be very suspicious of a dataset where $90 \%$ of the observations dropped out the year before they became widely held. Likewise, we would doubt the results using a sample where firms were more likely to drop from the sample the longer they were not widely held. Thus, we consider why we cease to observe firms' data in the sample after some length of time. The reasons are likely to be bankruptcy, mergers, failure to be included in one of our databases (Compact Disclosure, CRSP or Compustat, probably due to size but also possibly due to distress), and poor matching of datasets due to identifiers changing over time. The bankrupt firms cannot become widely held if they liquidate; the firms that disappear because of a merger with a public firm may become widely held as a result of the acquisition; the firms acquired by a private firm are much less likely to become widely held; and the remaining missing observations are probably truly randomly missing. We believe the overall impact is a set of missing observations that are random vis-à-vis the probability of becoming widely held.

Table 8 shows the results of the hazard model estimation. We use the same explanatory variables as in Table 6 except for insider ownership. It does not make sense to use insider ownership since our dependent variable is a step function of insider ownership. As before, we use the $10 \%$ and $20 \%$ thresholds for the definition of a widely-held firm. We report the number of events and the number of censored observations. It is immediately apparent, but not surprising given the results in Table 3, that the number of censored observations is large compared to the number of events. For the $10 \%$ threshold, $90.39 \%$ of the observations are censored observations. Recall that variables with positive coefficients shift the baseline 
hazard function upward, meaning firms with high values of these characteristics are more likely to become widely held.

We first turn to the results that hold irrespective of the definition of a widely held firm we adopt. As expected, firms with VC investments, larger firms, firms with a lower book-to-market ratio, firms with lower cash flow, firms with greater turnover, and firms with higher contemporaneous returns are more likely to become widely held irrespective of the definition of a widely held firm used. However, the threshold size variable is never significant. The coefficient on the book-to-market ratio seems inconsistent with the claims in the literature that a high Tobin's $q$ leads to greater insider ownership. Surprisingly, the ratio of plant, property, and equipment to assets has a negative significant coefficient. Further, firms that report R\&D are more likely to become widely held, which appears to be inconsistent with the predictions of the moral hazard and information asymmetry models. The coefficient on R\&D expenses is not significant. The coefficient on dividends is insignificant for the $10 \%$ threshold, but significantly positive at the $20 \%$ threshold.

The coefficient on leverage is significantly negative. Models that emphasize entrenchment by insiders are consistent with a negative coefficient, since in such models insiders would want high leverage so that they can afford a large fraction of the votes (see Stulz, 1988). With moral hazard theories, we would expect that higher leverage decreases ownership concentration since higher leverage keeps managers on a tighter leash (see Jensen, 1986, and Stulz, 1990). The evidence does not seem supportive of these theories. However, if high leverage is the outcome of financial distress, insiders would find it costly to decrease their ownership shares in a way that decreases leverage because doing so would involve issuing equity precisely when the underinvestment problem of Myers (1978) is likely to be severe. From a window of opportunity perspective, insiders might also think that their firm is undervalued when leverage is high, so that they would be reluctant to take actions that decrease their ownership share. 
The coefficient on volatility is significantly negative so that high volatility firms are less likely to become widely held. Volatility plays a dual role in the theories considered in this paper. ${ }^{24}$ High volatility forces insiders to bear more risk, which makes it more valuable for them to decrease their stake. However, high volatility also means greater information asymmetry and greater managerial discretion, which makes it costly for insiders to decrease their stake. Our evidence is consistent with Demsetz and Lehn (1985) who state that "noisier environments should give rise to more concentrated ownership structures" (p. 1159). In their empirical work, volatility is positively correlated with ownership concentration. Himmelberg, Hubbard, and Palia (1999) do not find a relation between ownership and volatility when they allow for firm fixed effects, but find a negative relation when they do not. As with our probit regression, turnover is strongly positively related to the probability of becoming widely held.

The contemporaneous return on the firm's stock is positively related to the probability that the firm will become widely held, but the lagged return is not. The insignificant coefficient on lagged return suggests that the windows of opportunity theory may not be an important determinant of the probability of becoming widely held since with that theory, firms would issue equity and insiders would sell after the firm has had high returns, but any strong conclusion should be tempered by the fact that contemporaneous returns have a significant positive coefficient. However, if there is an optimal level of insider ownership that is not trivial, firms that already have low insider ownership are unlikely to dilute the stake of insiders further just because of the existence of a window of opportunity since that might lead them to have too little insider ownership. In contrast, firms that have substantial insider ownership may have been waiting for the right conditions to dilute the stake of the insiders, but these firms are unlikely to become widely held.

We examined the robustness of our conclusions from the hazard function estimates in a variety of ways. In particular, we extended the sample to include firms for which insider ownership data was missing up to three years. We also used industry dummy variables and only lagged variables. Finally, we

\footnotetext{
${ }^{24}$ Prendergast (2002) shows that the empirical evidence on the relation between volatility and optimal managerial ownership is ambiguous and that on theoretical grounds the relation is complex.
} 
used only one size variable and one $R \& D$ variable. Our main conclusions are robust to these alternative specifications.

\section{Conclusion}

In this paper, we show that insider ownership falls steadily following the IPO. While half the firms have less than $20 \%$ insider ownership 10 years after the IPO, we have no post-IPO year in our sample where more than half the firms have more than $10 \%$ insider ownership. Nevertheless, compared to most countries, the fraction of firms with less than $10 \%$ of insider ownership is large as it exceeds $30 \% 10$ years after the IPO.

Surprisingly in light of the U.K. evidence, a major factor for the evolution of the ownership structure of U.S. firms is that insiders sell shares in substantial amounts, so that ownership becomes more diffuse about as much because of a reduction in shares held by insiders as because of an increase in shares outstanding. Moreover, the dilution that occurs via SEOs and mergers is only a fraction of the total dilution associated with increased shares outstanding.

We use two different approaches to understand why firms become widely held. With the first approach, we investigate the determinants of large decreases in ownership. Firms experience such large decreases mostly because the stock has a good market. In particular, the firm is highly valued by the markets, its stock market performance has been good, and its stock has enough liquidity so that more shares can be sold with limited market pressure. Further, when we try to explain the likelihood of large drops in insider ownership with recent changes in firm characteristics, the firm's contemporaneous and lagged stock-price changes are the only consistently significant variables. With the second approach, we estimate a hazard model that allows us to understand the determinants of a firm's conditional probability of becoming widely held. Again, we find that highly valued firms and high turnover firms are more likely to become widely held. With this approach, we estimate the probability that a firm will end up with 
diffuse ownership. We find that some variables emphasized by moral hazard and asymmetric information models significantly affect this probability in the predicted direction, but some do not.

Our results show that the market for a firm's stock and its stock's market performance are critical determinants of the evolution of its ownership. One might be tempted to conclude that it is so because these variables capture better the extent to which moral hazard and asymmetric information problems affect a firm. Such a conclusion finds little support in regressions without market variables, but it is possible that the variables we and the literature have used to proxy for moral hazard and asymmetric information problems do a poor job of capturing these problems. The evidence is much more supportive of a view that insiders sell shares and reduce their holdings when they can do so without putting too much pressure on the stock price by selling shares. Whether firms end up with really low insider ownership through that process does depend on variables that capture moral hazard and asymmetric information problems. Our regressions make stock market liquidity a key determinant of the composition of a firm's ownership. To the extent that liquidity is more easily obtained for smaller stocks in the U.S. than in most other countries, our results help understand why firms in the U.S. are more likely to be widely held. 


\section{References}

Anderson, R. C., and D. S. Lee, 1997, Ownership studies: The data source does matter, Journal of Financial and Quantitative Analysis 32, 311-329.

Atkins, A.B., and E.A. Dyl, 1997, Market structure and reported trading volume: NASDAQ versus the NYSE, Journal of Financial Research 20, 291-304.

Bagwell, L.S., 1991, Shareholder heterogeneity: Evidence and implications, American Economic Review $81,218-221$

Baker, M., J. Coval, and J.C. Stein, 2005. Corporate financing decisions when investors take the path of least resistance, unpublished paper, Harvard Economics Department, Cambridge, MA.

Baker, M., and P. A. Gompers, 2003, The determinants of board structure at the initial public offering, Journal of Law and Economics 46, 569-598.

Baker, M., and J. Stein, 2004, Market liquidity as a sentiment indicator, Journal of Financial Markets 7, 271-299.

Baker, M., and J. Wurgler, 2002, Market timing and capital structure, Journal of Finance 57, 1-32.

Becht, M., and B. de Long, 2005, Why has there been so little blockholding in America?, unpublished paper, University of California at Berkeley, Berkeley, CA.

Berle, A, and G. Means, 1932, The modern corporation and private property, McMillan, New York, NY.

Benninga, S., Helmantel, and O. Sarig, 2005, The timing of initial public offerings, Journal of Financial Economics 75, 115-132.

Chen, J., H. Hong, and J. C. Stein, 2001, Forecasting crashes: Trading volume, past returns, and conditional skewness in stock prices, Journal of Financial Economics 61, 345-381.

Chordia, T., S.-W. Huh, and A. Subrahmanyam, 2004, The cross-section of expected trading activity, unpublished working paper, UCLA, Los Angeles, CA.

Clarke, J., C. Dunbar and K. Kahle, 2004, The long-run performance of secondary equity issues: A test of the windows of opportunity hypothesis, Journal of Business 77, 575-603.

Cox, D., 1975, Partial likelihood, Biometrika 62, 269-276.

Crutchley, C.E., and R.S. Hansen, 1989, A test of the agency theory of managerial ownership, corporate leverage, and corporate dividends, Financial Management (Winter), 36-46.

Demsetz, H., and K. Lehn, 1985, The structure of corporate ownership: Cause and consequences, Journal of Political Economy 93, 1155-1177.

Demsetz, H., and B. Villalonga, 2001, Ownership structure and corporate performance, Journal of Corporate Finance 7, 209-233. 
Dierkens, N., 1991, Information asymmetry and equity issues, Journal of Financial and Quantitative Analysis 26, 181-200.

Doidge, C., A. Karolyi, K. Lins, D. Miller and R. Stulz 2005, Private benefits of control, ownership, and the cross-listing decision, unpublished working paper, The Ohio State University, Columbus, $\mathrm{OH}$.

Fama, E., and K. French, 2005, Financing decisions: Who issues stock?, Journal of Financial Economics, 549-582.

Fama, E., and M.C. Jensen, 1983, Separation of ownership and control, Journal of Law and Economics $26,302-325$.

Field, L. C., and G. Hanka, 2001, The expiration of IPO share lockups, Journal of Finance 56, 471-500.

Franks, J., C. Mayer, and S. Rossi, 2004, Ownership: Evolution and Regulation, unpublished working paper, London Business School, London, U.K.

Gertler, M. and R. G. Hubbard, 1993, Corporate financial policy, taxation, and macroeconomic risk, Rand Journal of Economics 24, 286-303.

Gompers, P., J. Ishii, and A. Metrick, 2004, Incentives vs. control: An analysis of the U.S. dual-class companies, unpublished working paper, The Wharton School, University of Pennsylvania, Philadelphia, PA.

Helwege, J., 1996, Determinants of savings and loan failures: Estimates of a time-varying proportional hazard function, Journal of Financial Services Research 10, 373-392.

Himmelberg, C. P., R. G. Hubbard and D. Palia, 1999, Understanding the determinants of managerial ownership and the link between ownership and performance, Journal of Financial Economics 53, 353384.

Holderness, C., R. Kroszner, and D. Sheehan, 1999, Were the good old days that good? Changes in managerial stock ownership since the great depression, Journal of Finance 54, 435-469.

Jensen, M. C., 1986, Agency costs of free cash flow, corporate finance, and takeovers, American Economic Review 76, 323-329.

Jensen, M. C., and W. H. Meckling, 1976, Theory of the firm: Managerial behavior, agency costs and ownership structure, Journal of Financial Economics 3, 305-360.

Kaniel, R., G. Saar, and S. Titman, 2004, Individual investor sentiment and stock returns, unpublished working paper, University of Texas, Austin, TX.

Keim, D.B., and A. Madhavan, 1996, The upstairs market for large-block transactions: Analysis and measurement of price effects, Review of Financial Studies 9, 1-36.

La Porta, R., F. Lopez-De-Silanes and A. Shleifer, 1999, Corporate ownership around the world, Journal of Finance 54, 471-517. 
Lane, W.R., S.W. Looney, and J.W. Wansley, 1986, An application of the Cox proportional hazards model to bank failure, Journal of Banking and Finance 10, 511-532.

Leland, H. E., and D. H. Pyle, 1977, Informational asymmetries, financial structure, and financial intermediation, Journal of Finance 32, 371-387.

Maug, E., 2001, Ownership structure and the life-cycle of the firm: A theory of the decision to go public, European Finance Review 5, 167-200.

McConnell, J., H. Servaes, and K. Lins, 2005, Changes in equity ownership and changes in the market value of the firm, unpublished working paper, London Business School.

McDonald, C.G., and L.M. Van de Gucht, 1999, High-yield bond default and call risks, Review of Economics and Statistics 18, 409-419.

Mikkelson, W., M.M. Partch, and K. Shah, 1997, Ownership and operating performance of companies that go public, Journal of Financial Economics 44, 281-307.

Moeller, S., F. Schlingemann, and R.M. Stulz, 2005, Does investor diversity of opinion, information asymmetry, or uncertainty resolution affect acquirer returns?, unpublished working paper, Fisher College of Business, The Ohio State University.

Myers, S.C., and N.S. Majluf, 1984, Corporate financing and investment decisions when firms have information that investors do not have, Journal of Financial Economics 13, 187-221.

Pastor, L, and P. Veronesi, 2005, Rational IPO waves, Journal of Finance, forthcoming.

Prendergast, C., 2002, The tenuous trade-off between risk and incentives, Journal of Political Economy $110,1071-1102$.

Roe, M., 2003, Political Determinants of Corporate Governance, Oxford University Press, Oxford.

Schultz, Paul, 2003, Pseudo market timing and the long-run underperformance of IPOs, Journal of Finance 58, 483-518.

Schwartz, E.S. and W.N. Torous, 1993, Mortgage prepayment and default decisions: A Poisson regression approach, American Real Estate and Urban Economics Association 21, 431-449.

Shleifer, Andrei and Robert W. Vishny, 1997, A survey of corporate governance, Journal of Finance 52, 737-783.

Shumway, T., 2001, Forecasting bankruptcy more accurately: A simple hazard model, Journal of Business 74, 101-124.

Stulz, R. M., 1988, Managerial control of voting rights: Financing policies and the market for corporate control, Journal of Financial Economics 20, 25-54.

Stulz, R. M., 1990, Managerial discretion and optimal financing policies, Journal of Financial Economics $26,3-28$. 
Subrahmanyam, A., and S. Titman, 1999, The going-public decision and the development of financial markets, Journal of Finance 54, 1045-1082.

Whalen, G., 1991, A proportional hazards model of bank failure: An examination of its usefulness as an early warning tool, FRB Cleveland - Economic Review 27, 21-31.

Zhou, X., 2001, Understanding the determinants of managerial ownership and the link between ownership and performance: comment, Journal of Financial Economics 62, 559-571. 
Table 1

Description of the IPO Sample

The first column shows the number of IPOs in SDC Platinum that went public between 1970 and 2001, excluding unit offerings, rights offerings, reverse LBOs, and spin-offs. The second column reports the subset of these firms that are in CRSP from 1986 to 2001, excluding utilities and financial firms (based on SIC codes reported in CRSP). The third column reports the number of firms with non-missing insider ownership information in Compact Disclosure for at least one year over the 1986-2001 period.

\begin{tabular}{|c|c|c|c|}
\hline Year & $\begin{array}{l}\text { Sample from SDC } \\
\text { Platinum }\end{array}$ & $\begin{array}{l}\text { Sample after } \\
\text { merging with } \\
\text { CRSP and } \\
\text { excluding utilities } \\
\text { and financials }\end{array}$ & $\begin{array}{c}\text { Sample after } \\
\text { merging with } \\
\text { Compact Disclosure } \\
\text { requiring one year of } \\
\text { ownership data }\end{array}$ \\
\hline 1970 & 218 & 109 & 27 \\
\hline 1971 & 238 & 167 & 58 \\
\hline 1972 & 467 & 365 & 104 \\
\hline 1973 & 91 & 48 & 16 \\
\hline 1974 & 8 & 6 & 3 \\
\hline 1975 & 6 & 5 & 3 \\
\hline 1976 & 39 & 29 & 10 \\
\hline 1977 & 27 & 16 & 5 \\
\hline 1978 & 35 & 27 & 13 \\
\hline 1979 & 59 & 43 & 21 \\
\hline 1980 & 125 & 88 & 47 \\
\hline 1981 & 278 & 223 & 124 \\
\hline 1982 & 88 & 83 & 46 \\
\hline 1983 & 521 & 412 & 331 \\
\hline 1984 & 243 & 175 & 132 \\
\hline 1985 & 245 & 164 & 143 \\
\hline 1986 & 524 & 308 & 280 \\
\hline 1987 & 380 & 227 & 209 \\
\hline 1988 & 217 & 95 & 90 \\
\hline 1989 & 172 & 102 & 101 \\
\hline 1990 & 152 & 96 & 86 \\
\hline 1991 & 277 & 201 & 198 \\
\hline 1992 & 419 & 258 & 253 \\
\hline 1993 & 638 & 382 & 376 \\
\hline 1994 & 491 & 336 & 331 \\
\hline 1995 & 485 & 401 & 396 \\
\hline 1996 & 749 & 587 & 570 \\
\hline 1997 & 537 & 375 & 367 \\
\hline 1998 & 352 & 224 & 211 \\
\hline 1999 & 506 & 400 & 384 \\
\hline 2000 & 363 & 315 & 301 \\
\hline 2001 & 107 & 52 & 45 \\
\hline Total & 9,057 & 6,319 & 5,281 \\
\hline
\end{tabular}


Table 2

Distribution of the Levels of Insider Ownership Following an IPO

Shares held by insiders as a percent of outstanding shares. The WH10 (WH20) column presents the fraction of firms with a percentage insider ownership less than $10 \%(20 \%)$ of total number of shares outstanding (widely held firms). The initial sample is from SDC Platinum and covers all firms that went public between 1970 and 2001, excluding unit offerings, rights offerings, reverse LBOs, spin-offs, utilities and financial firms. Insider ownership is sampled annually from Compact Disclosure from 1986 to 2001 .

\begin{tabular}{lccccccc}
\hline & Mean & Q25 & Median & Q75 & WH10 & WH20 & $\begin{array}{c}\text { Number of } \\
\text { Firms }\end{array}$ \\
\hline Year1 & 38.22 & 20.57 & 38.13 & 55.34 & 12.43 & 24.27 & 3878 \\
Year3 & 30.50 & 12.76 & 26.46 & 46.01 & 19.68 & 39.77 & 3460 \\
Year5 & 27.27 & 9.58 & 21.11 & 41.48 & 26.54 & 48.14 & 2634 \\
Year10 & 24.15 & 7.52 & 18.33 & 35.52 & 31.73 & 52.71 & 958 \\
Year15 & 24.57 & 8.07 & 18.26 & 35.28 & 33.27 & 54.16 & 517 \\
Year20 & 23.19 & 6.23 & 16.59 & 34.76 & 37.05 & 53.57 & 224 \\
Year25 & 20.25 & 5.02 & 14.68 & 29.27 & 42.86 & 63.27 & 98 \\
Year30 & 21.83 & 5.93 & 16.48 & 33.95 & 37.14 & 60.00 & 70 \\
Year32 & 15.40 & 4.04 & 8.88 & 22.49 & 50.00 & 58.33 & 12 \\
\hline
\end{tabular}


Table 3

Probability that a Firm's Ownership will Become Diffuse in a Given Year after its IPO

The random variables, $T^{10}$ and $T^{20}$, are defined as the first down-crossing by the percentage of insider ownership of the threshold barriers of 10 percent and 20 percent, respectively. The conditional probability that a firm will become widely-held over year $k$, conditional on not being widely held prior to that year, $\operatorname{Pr}\left\{T^{10}=k \mid T^{10} \geq k\right\}$, is obtained by dividing the number of all firms that become widely held over year $k$ by the total number of firms that are ' $\mathrm{k}$-years old' and that were never widely held up to this point. The sample includes only firms that went public between 1986 and 2001 with non-missing insider ownership information from the year of the IPO until they exit the sample. The IPO sample is from SDC Platinum and excludes unit offerings, rights offerings, reverse LBOs, spin-offs, utilities and financial firms. Insider ownership is sampled annually from Compact Disclosure over the 1986-2001 period. The table also reports the total number of firms, the number of firms becoming widely held, and the number of firms leaving the sample each year due to censoring.

\begin{tabular}{lcccccccc}
\hline Year & $\operatorname{Pr}\left\{T^{10}\right\}$ & $\begin{array}{c}\text { Total } \\
\text { Number } \\
\text { of Firms }\end{array}$ & $\begin{array}{c}\text { Number } \\
\text { of Firms } \\
\text { Becoming } \\
\text { Widely } \\
\text { Held }\end{array}$ & $\begin{array}{c}\text { Number } \\
\text { of Firms } \\
\text { Leaving } \\
\text { the } \\
\text { Sample }\end{array}$ & $\operatorname{Pr}\left\{T^{20}\right\}$ & $\begin{array}{c}\text { Total } \\
\text { Number } \\
\text { of Firms }\end{array}$ & $\begin{array}{c}\text { Number } \\
\text { of Firms } \\
\text { Becoming } \\
\text { Widely } \\
\text { Held }\end{array}$ & $\begin{array}{c}\text { Number } \\
\text { of Firms } \\
\text { Leaving } \\
\text { the } \\
\text { Sample }\end{array}$ \\
\hline 1 & 0.12 & 3878 & 482 & 530 & 0.24 & 3878 & 941 & 456 \\
2 & 0.06 & 2866 & 166 & 635 & 0.15 & 2481 & 362 & 523 \\
3 & 0.07 & 2065 & 135 & 541 & 0.13 & 1596 & 201 & 418 \\
4 & 0.07 & 1389 & 93 & 344 & 0.13 & 977 & 126 & 232 \\
5 & 0.08 & 952 & 74 & 219 & 0.10 & 619 & 64 & 142 \\
6 & 0.05 & 659 & 35 & 181 & 0.09 & 413 & 39 & 101 \\
7 & 0.07 & 443 & 30 & 104 & 0.10 & 273 & 27 & 64 \\
8 & 0.08 & 309 & 24 & 86 & 0.06 & 182 & 11 & 55 \\
9 & 0.05 & 199 & 9 & 72 & 0.05 & 116 & 6 & 44 \\
10 & 0.05 & 118 & 6 & 39 & 0.06 & 66 & 4 & 25 \\
11 & 0.14 & 73 & 10 & 19 & 0.03 & 37 & 1 & 8 \\
12 & 0.07 & 44 & 3 & 7 & 0.11 & 28 & 3 & 5 \\
13 & 0.00 & 34 & 0 & 4 & 0.10 & 20 & 2 & 3 \\
14 & 0.10 & 30 & 3 & 6 & 0.07 & 15 & 1 & 3 \\
15 & 0.05 & 21 & 1 & 6 & 0.18 & 11 & 2 & 2 \\
\hline
\end{tabular}


Table 4

\section{How Do Large Drops in Insider Ownership Take Place?}

A large drop in insider ownership is defined as a drop of at least five percentage points of insider ownership defined as the percent of shares owned by insiders. The change in insider ownership is decomposed into two parts, the first one due to the change in number of shares held by insiders (changes in the numerator of fractional ownership) and the second one due to the change in total number of shares outstanding (changes in the denominator of fractional ownership). The fraction of shares sold in secondary offerings, as well as the fraction of shares issued in SEOs and to pay for mergers, are obtained from SDC. We compute these fractions over a three year window centered in the year for which the firm experiences a drop in insider ownership that exceeds $5 \%$.

\begin{tabular}{lccccc}
\hline & $\begin{array}{c}\text { Change in } \\
\text { ownership } \\
\text { share }\end{array}$ & $\begin{array}{c}\text { Changes in numerator } \\
\text { Due to } \\
\text { change in } \\
\text { shares held } \\
\text { by insiders }\end{array}$ & $\begin{array}{c}\text { Due to } \\
\text { secondary } \\
\text { share sales } \\
\text { in SEOs }\end{array}$ & $\begin{array}{c}\text { Changes in denominator } \\
\text { Due to } \\
\text { change in } \\
\text { the number } \\
\text { of shares }\end{array}$ & $\begin{array}{c}\text { Due to } \\
\text { SEOs and } \\
\text { mergers }\end{array}$ \\
\hline Mean & -0.15 & -0.08 & -0.02 & -0.07 & -0.01 \\
$1 \%$ & -0.63 & -0.60 & -0.28 & -0.64 & -0.15 \\
Q1 & -0.19 & -0.14 & 0.00 & -0.09 & -0.00 \\
Median & -0.11 & -0.07 & 0.00 & -0.02 & 0.00 \\
Q3 & -0.08 & -0.02 & 0.00 & -0.00 & 0.00 \\
$99 \%$ & -0.05 & 0.46 & 0.00 & 0.04 & 0.00 \\
\hline
\end{tabular}


Table 5

Firm Characteristics of Firms Experiencing a Large Ownership Drop and of Other Sample Firms

The initial sample is from SDC Platinum and covers all firms that went public between 1970 and 2001, excluding unit offerings, rights offerings, reverse LBOs, spin-offs, utilities and financial firms. All variables except contemporaneous returns are measured at the end of the year preceding the large drop in ownership. The firm characteristics are: the percentage of insider ownership at the beginning of the year (INSD); a venture capital dummy (VC), equal to one if the IPO is venture-capital backed; the logarithm of book-value-of-assets (LBVA) in 1970 dollars; an indicator variable for the bottom size quartile based on NYSE-breakpoints (SZIND); book-to-market equity ratio (BME); property, plant, and equipment over total assets (PPEA); free cash flows (FCF), defined as EBITDA over sales; capital expenditures over assets (CEXPA); research and development expenditures over assets (RDA); an R\&D dummy (RDIND), equal to 1 if the firm has positive Research and Development expenditures for that year; a dividend dummy (DIVIND), equal to 1 if the firm has paid a dividend in that year; leverage (LVRG), defined as total liabilities over book value of assets; idiosyncratic volatility for year $t$ is the residual from a market model regression estimated using daily data for year $t$ (VOLATILITY); average daily turnover for NYSE traded stocks and zero, otherwise (TONYSE); average daily turnover for NASDAQ traded stocks and zero, otherwise (TONASD); firm-, industry- and market-returns over the previous fiscal year (LAGRET, LAGIRET, and LAGMRET); and firm-, industry- and market-returns over the current fiscal year (RET, IRET, and MRET). $\left({ }^{* *}\right),\left({ }^{*}\right)$, and $(*)$ indicate statistical significance at the $1 \%, 5 \%$, and $10 \%$ level, respectively.

\begin{tabular}{lccccll}
\hline & Mean & Mean & Median & Median & & \\
& $(>5 \%$ drop $)$ & $(<5 \%$ drop $)$ & $(>5 \%$ drop $)$ & $(<5 \%$ drop $)$ & Diff.Mean & Diff.Median \\
\hline INSD & 0.413 & 0.356 & 0.386 & 0.317 & $0.057^{* * *}$ & $0.070^{* * *}$ \\
VC & 0.464 & 0.356 & 0.000 & 0.000 & $0.108^{* * *}$ & --- \\
LBVA & 2.757 & 2.813 & 2.682 & 2.769 & $-0.057^{* *}$ & $-0.087^{* * *}$ \\
SZIND & 0.898 & 0.889 & 1.000 & 1.000 & 0.009 & --- \\
BME & 0.471 & 0.648 & 0.350 & 0.493 & $-0.177^{* * *}$ & $-0.143^{* * *}$ \\
PPEA & 0.229 & 0.258 & 0.156 & 0.190 & $-0.029^{* * *}$ & $-0.034^{* * *}$ \\
FCF & -0.099 & -0.012 & 0.088 & 0.089 & $-0.087^{* * *}$ & $-0.001^{* * *}$ \\
CEXPA & 0.077 & 0.079 & 0.049 & 0.050 & -0.001 & -0.001 \\
RDA & 0.089 & 0.062 & 0.009 & 0.000 & $0.027^{* * *}$ & $0.009^{* * *}$ \\
RDIND & 0.526 & 0.469 & 1.000 & 0.000 & $0.057^{* * *}$ & --- \\
DIVIND & 0.169 & 0.194 & 0.000 & 0.000 & $-0.025^{* * *}$ & --- \\
LVRG & 0.415 & 0.430 & 0.377 & 0.406 & $-0.015^{* * *}$ & $-0.029^{* * *}$ \\
VOLATILITY & 0.048 & 0.046 & 0.043 & 0.041 & $0.002^{* * *}$ & $0.002^{* * *}$ \\
TONYSE & 0.040 & 0.043 & 0.000 & 0.000 & -0.003 & 0.000 \\
TONASD & 0.717 & 0.545 & 0.479 & 0.356 & $0.172^{* * *}$ & $0.123^{* * *}$ \\
LAGRET & 0.217 & 0.089 & 0.040 & -0.051 & $0.129^{* * *}$ & $0.091^{* * *}$ \\
LAGIRET & 0.179 & 0.148 & 0.137 & 0.110 & $0.032^{* * *}$ & $0.027^{* * *}$ \\
LAGMRET & 0.164 & 0.159 & 0.213 & 0.213 & $0.005^{* *}$ & 0.000 \\
RET & 0.230 & 0.067 & 0.094 & -0.065 & $0.232^{* * *}$ & $0.159^{* * *}$ \\
IRET & 0.163 & 0.131 & 0.137 & 0.096 & $0.033^{* * *}$ & $0.041^{* * *}$ \\
MRET & 0.145 & 0.135 & 0.213 & 0.213 & $0.010^{* * *}$ & 0.000 \\
\hline
\end{tabular}




\section{Table 6 \\ Determinants of the Probability of a 5\% or Greater Annual Drop in Insider Ownership}

Probit model parameter estimates of the probability of a 5\% or greater drop in insider ownership in a year conditional on the insider ownership at the beginning of the year being greater than $10 \%$. The pooled estimates use all firm-year observations, whereas "Yr. 6-32" pools data in years 6 though 32. The sample includes all firms in SDC Platinum that went public between 1970 and 2001, except unit offerings, rights offerings, reverse LBOs, spinoffs, utilities and financial firms. The independent variables are: the percentage of insider ownership at the beginning of the year (INSD); a venture capital dummy (VC), equal to one if the IPO is venture-capital backed; the logarithm of book-value-of-assets in 1970 dollars (LBVA); an indicator variable for the bottom size quartile based on NYSE-breakpoints (SZIND); book-to-market equity ratio (BME); property, plant, and equipment over total assets (PPEA); free cash flows (FCF), defined as EBITDA over sales; capital expenditures over assets (CEXPA); research and development expenditures over assets (RDA); an R\&D dummy (RDIND), equal to 1 if the firm has positive Research and Development expenditures for that year; a dividend dummy (DIVIND), equal to 1 if the firm has paid a dividend in that year; leverage (LVRG), defined as total liabilities over book value of assets; idiosyncratic volatility estimated from a market model and based on daily returns (VOLATILITY); average daily turnover for NYSE traded stocks and zero, otherwise (TONYSE); average daily turnover for NASDAQ traded stocks and zero, otherwise (TONASD); firm-, industry- and market-returns over the previous fiscal year (LAGRET, LAGIRET, and LAGMRET); and firm-, industry- and market-returns over the current fiscal year (RET, IRET, and MRET). All accounting variables are sampled at the end of the previous fiscal year. The last two rows report the number of firms experiencing a $5 \%$ or greater drop (NOBS $=1$ ) and the number of firms that did not experience a $5 \%$ or greater drop in insider ownership (NOBS $=0) .(* * *),(* *)$, and $(*)$ indicate statistical significance at the $1 \%$, $5 \%$, and $10 \%$ level, respectively.

\begin{tabular}{llllllll}
\hline & Pooled & Yr.1 & Yr.2 & Yr.3 & Yr.4 & Yr.5 & Yr.6-32 \\
\hline Intercept & $-1.427^{* * *}$ & $-1.311^{* * *}$ & $-1.101^{* * *}$ & $-1.066^{* * *}$ & $-0.796^{* *}$ & $-1.683^{* * *}$ & $-1.524^{* * *}$ \\
INSD & $1.402^{* * *}$ & $1.100^{* * *}$ & $1.416^{* * *}$ & $0.693^{* * *}$ & $1.148^{* * *}$ & $1.536^{* * *}$ & $1.149^{* * *}$ \\
VC & $0.256^{* * *}$ & $0.356^{* * *}$ & $0.259^{* * *}$ & -0.050 & $0.183^{* *}$ & $0.241^{* *}$ & $0.170^{* * *}$ \\
LBVA & $0.043^{* * *}$ & $0.137^{* * *}$ & $0.068^{*}$ & 0.030 & $-0.086^{* *}$ & -0.025 & 0.024 \\
SZIND & 0.019 & 0.048 & -0.101 & 0.071 & $-0.353^{* *}$ & -0.008 & -0.009 \\
BME & $-0.310^{* * *}$ & $-0.733^{* * *}$ & $-0.230^{* * *}$ & $-0.169^{* *}$ & $-0.202^{* *}$ & -0.072 & $-0.230^{* * *}$ \\
PPEA & $-0.186^{* *}$ & -0.077 & -0.300 & -0.075 & -0.238 & 0.050 & $0.014^{*}$ \\
FCF & $-0.134^{* * *}$ & -0.051 & $-0.120^{* *}$ & $-0.124^{*}$ & $-0.120^{*}$ & -0.017 & $-0.091^{* * *}$ \\
CEXPA & 0.067 & -0.174 & 0.120 & -0.100 & 0.526 & -0.081 & -0.158 \\
RDA & $0.371^{* * *}$ & $0.892^{*}$ & $0.654^{*}$ & $0.883^{* *}$ & 0.526 & -0.202 & $0.483^{*}$ \\
RDIND & $-0.083^{* * *}$ & -0.092 & -0.107 & -0.113 & $-0.321^{* * *}$ & -0.178 & 0.044 \\
DIVIND & -0.013 & -0.005 & -0.114 & 0.125 & 0.134 & -0.053 & -0.029 \\
LVRG & -0.017 & -0.099 & $-0.357^{* *}$ & -0.067 & 0.097 & -0.022 & $0.417^{* * *}$ \\
VOLATILITY & $1.210^{*}$ & $4.210^{* *}$ & -1.049 & 1.015 & 1.499 & 1.581 & -0.331 \\
TONYSE & $0.177^{* *}$ & 0.149 & -0.195 & 0.152 & $0.549^{* *}$ & 0.102 & 0.132 \\
TONASD & $0.173^{* * *}$ & $0.094^{* * *}$ & $0.174^{* * *}$ & 0.055 & $0.181^{* *}$ & $0.310^{* * *}$ & $0.081^{*}$ \\
LAGRET & $0.093^{* * *}$ & $0.124^{* *}$ & 0.065 & $0.138^{* *}$ & $0.191^{* * *}$ & $0.111^{*}$ & $0.112^{* * *}$ \\
LAGIRET & $0.091^{*}$ & 0.127 & 0.151 & -0.004 & 0.156 & 0.043 & -0.001 \\
LAGMRET & -0.092 & -0.097 & 0.160 & -0.047 & -0.042 & 0.035 & -0.207 \\
RET & $0.283^{* * *}$ & $0.338^{* * *}$ & $0.382^{* * *}$ & $0.213^{* * *}$ & $0.346^{* * *}$ & $0.258^{* * *}$ & $0.263^{* * *}$ \\
IRET & 0.069 & 0.074 & 0.038 & 0.228 & 0.179 & 0.299 & 0.057 \\
MRET & $0.215^{* *}$ & 0.331 & 0.040 & 0.364 & 0.093 & 0.346 & -0.042 \\
NOBS $=1$ & 3,460 & 849 & 616 & 440 & 333 & 227 & 995 \\
NOBS $=0$ & 9,712 & 1,147 & 1,338 & 1,123 & 1,051 & 901 & 4,152 \\
\hline
\end{tabular}


Table 7

\section{Determinant of the Probability of a 5\% or Greater Annual Drop in Insider Ownership Using Lagged Changes in the Explanatory Variables}

Probit model parameter estimates of the probability for a $5 \%$ or greater annual drop in insider ownership conditional on insider ownership at the beginning of the year greater than $10 \%$. The pooled estimates use all firm-year observations, whereas "Yr. 6-32" pools data in years 6 though 32. The sample includes all IPOs in SDC Platinum that occurred between 1970 and 2001, except unit offerings, rights offerings, reverse LBOs, spin-offs, utilities and financial firms. The independent variables include the percentage of insider ownership at the beginning of the year (INSD); firm-, industry- and market-returns over the previous fiscal year (LAGRET, LAGIRET, and LAGMRET); firm-, industry- and market-returns over the current fiscal year (RET, IRET, and MRET); and lagged changes in the following variables: the logarithm of book-value-of-assets in 1970 dollars (DLBVA(t-1)); an indicator variable for the bottom size quartile based on NYSE-breakpoints (DSZIND(t-1)); book-to-market equity ratio (DBME(t-1)); property, plant, and equipment over total assets (DPPEA(t-1)); free cash flow (DFCF(t-1)), defined as EBITDA over sales; capital expenditures over assets (DCEXPA(t-1)); research and development expenditures over assets (DRDA(t-1)); an R\&D dummy (DRDIND(t-1)), equal to 1 if the firm has positive R\&D expenditures for that year; a dividend dummy (DDIVIND(t-1)), equal to 1 if the firm has paid a dividend in that year; leverage (DLVRG(t-1)), defined as total liabilities over book value of assets; idiosyncratic volatility estimated with daily returns (DVOLATILITY(t-1)); average daily turnover for NYSE traded stocks and zero, otherwise (DTONYSE(t-1)); average daily turnover for NASDAQ traded stocks and zero, otherwise (DTONASD(t-1)). All accounting variables are sampled at the end of the previous fiscal year. The last two rows report the number of firms that did experience a $5 \%$ drop $(\mathrm{NOBS}=1)$ and the number that did not $(\mathrm{NOBS}=0) .(* * *),(* *)$, and $(*)$ indicate statistical significance at the $1 \%, 5 \%$, and $10 \%$ level, respectively.

\begin{tabular}{lllllll}
\hline & Pooled & Yr.2 & Yr.3 & Yr.4 & Yr.5 & Yr.6-32 \\
\hline Intercept & $-1.390^{* * *}$ & $-1.349^{* * *}$ & $-0.968^{* * *}$ & $-1.241^{* * *}$ & $-1.587^{* * *}$ & $-1.359^{* * * *}$ \\
INSD & $1.054^{* * *}$ & $1.338^{* * *}$ & $0.515^{* * *}$ & $0.850^{* * *}$ & $1.373^{* * *}$ & $0.940^{* * *}$ \\
VC & $0.259^{* * *}$ & $0.422^{* * *}$ & 0.030 & 0.130 & $0.207^{* *}$ & $0.227^{* * *}$ \\
DLBVA(t-1) & $0.246^{* * *}$ & $0.181^{*}$ & $0.245^{* *}$ & 0.087 & -0.151 & $0.188^{* *}$ \\
DSZIND(t-1) & -0.059 & -0.165 & 0.194 & $-0.362^{*}$ & -0.047 & -0.021 \\
DBME(t-1) & $-0.082^{* *}$ & -0.173 & $-0.210^{*}$ & -0.065 & 0.057 & $-0.112^{*}$ \\
DPPEA(t-1) & $0.673^{* * *}$ & 0.137 & -0.440 & 0.712 & 0.456 & $0.768^{*}$ \\
DFCF(t-1) & -0.027 & 0.045 & 0.054 & 0.012 & -0.027 & $-0.286^{* * *}$ \\
DCEXPA(t-1) & -0.357 & -0.447 & -0.067 & 0.597 & 0.278 & -0.254 \\
DRDA(t-1) & $0.699^{* *}$ & 0.968 & $1.713^{* * *}$ & -0.518 & 0.467 & -0.428 \\
DRDIND(t-1) & -0.023 & $-0.480^{*}$ & 0.019 & 0.372 & -0.309 & 0.140 \\
DDIVIND(t-1) & 0.014 & $0.194 * *$ & 0.054 & 0.188 & 0.065 & -0.116 \\
DLVRG(t-1) & -0.014 & -0.063 & -0.362 & 0.398 & -0.483 & 0.099 \\
DVOLATILITY(t-1) & $1.620^{*}$ & -2.175 & $4.334^{*}$ & 1.336 & 0.471 & 1.064 \\
DTONYSE(t-1) & 0.006 & -0.061 & 0.160 & 0.071 & 0.198 & 0.007 \\
DTONASD(t-1) & -0.002 & 0.038 & 0.012 & 0.029 & 0.086 & -0.017 \\
LAGRET & $0.146^{* * *}$ & 0.052 & $0.111^{*}$ & $0.216^{* * *}$ & $0.189 * *$ & $0.155^{* * *}$ \\
LAGIRET & 0.024 & 0.246 & 0.011 & 0.104 & -0.007 & -0.030 \\
LAGMRET & 0.012 & 0.204 & -0.018 & -0.080 & 0.163 & -0.183 \\
RET & $0.268^{* * *}$ & $0.401 * * *$ & $0.217^{* * *}$ & $0.329 * * *$ & $0.229 * * *$ & $0.256^{* * *}$ \\
IRET & 0.096 & 0.026 & $0.284^{*}$ & 0.100 & 0.268 & 0.011 \\
MRET & $0.160^{*}$ & -0.075 & 0.381 & 0.143 & 0.204 & 0.028 \\
NOBS $=1$ & 2,294 & 455 & 406 & 287 & 218 & 928 \\
NOBS $=0$ & 7,760 & 1,045 & 1,030 & 887 & 871 & 3,927 \\
\hline
\end{tabular}


Table 8

Hazard Rate Model for the Event of Becoming Widely Held

Estimates of a hazard rate model for the event of becoming widely held, where a firm is defined to be widely held if its insider ownership is less than 10\% (the first two columns of the table) or less than $20 \%$ (the last two columns of the table). The sample includes only firms that went public between 1986 and 2001 with non-missing insider ownership information from the year of the IPO until they exit the sample (continuous sample). The explanatory variables are the variables listed in Table 5.

\begin{tabular}{lcccc}
\hline & $10 \%$ & $\mathrm{p}$-value & $20 \%$ & p-value \\
\hline VC & 0.454 & 0.000 & 0.817 & 0.000 \\
LBVA & 0.203 & 0.000 & 0.130 & 0.000 \\
SZIND & -0.104 & 0.489 & -0.207 & 0.106 \\
BME & -0.781 & 0.000 & -0.600 & 0.000 \\
PPEA & -0.626 & 0.040 & -0.826 & 0.001 \\
FCF & -0.135 & 0.025 & -0.159 & 0.000 \\
CEXPA & 0.805 & 0.198 & 0.677 & 0.187 \\
RDA & 0.013 & 0.972 & -0.308 & 0.309 \\
RDIND & 0.261 & 0.015 & 0.249 & 0.002 \\
DIVIND & 0.008 & 0.943 & 0.179 & 0.040 \\
LVRG & -0.384 & 0.061 & -0.572 & 0.001 \\
VOLATILITY & -8.872 & 0.003 & -7.904 & 0.000 \\
TONYSE & 0.755 & 0.000 & 0.654 & 0.000 \\
TONASD & 0.192 & 0.000 & 0.167 & 0.000 \\
LAGRET & -0.079 & 0.171 & -0.058 & 0.204 \\
LAGIRET & 0.470 & 0.009 & 0.727 & 0.000 \\
LAGMRET & -0.851 & 0.005 & -0.760 & 0.002 \\
RET & 0.170 & 0.000 & 0.168 & 0.000 \\
IRET & -0.017 & 0.921 & -0.170 & 0.206 \\
MRET & 1.011 & 0.001 & 0.902 & 0.000 \\
Number of events & 661 & & 1,081 & \\
Number of & & & & \\
censored obs. & 6,925 & & 5,145 & \\
Likelihood ratio & 375.01 & & 687.72 & \\
Chi-square test & & & & \\
for likelihood & & & & \\
ratio p-value & 0.0001 & & & \\
\hline
\end{tabular}




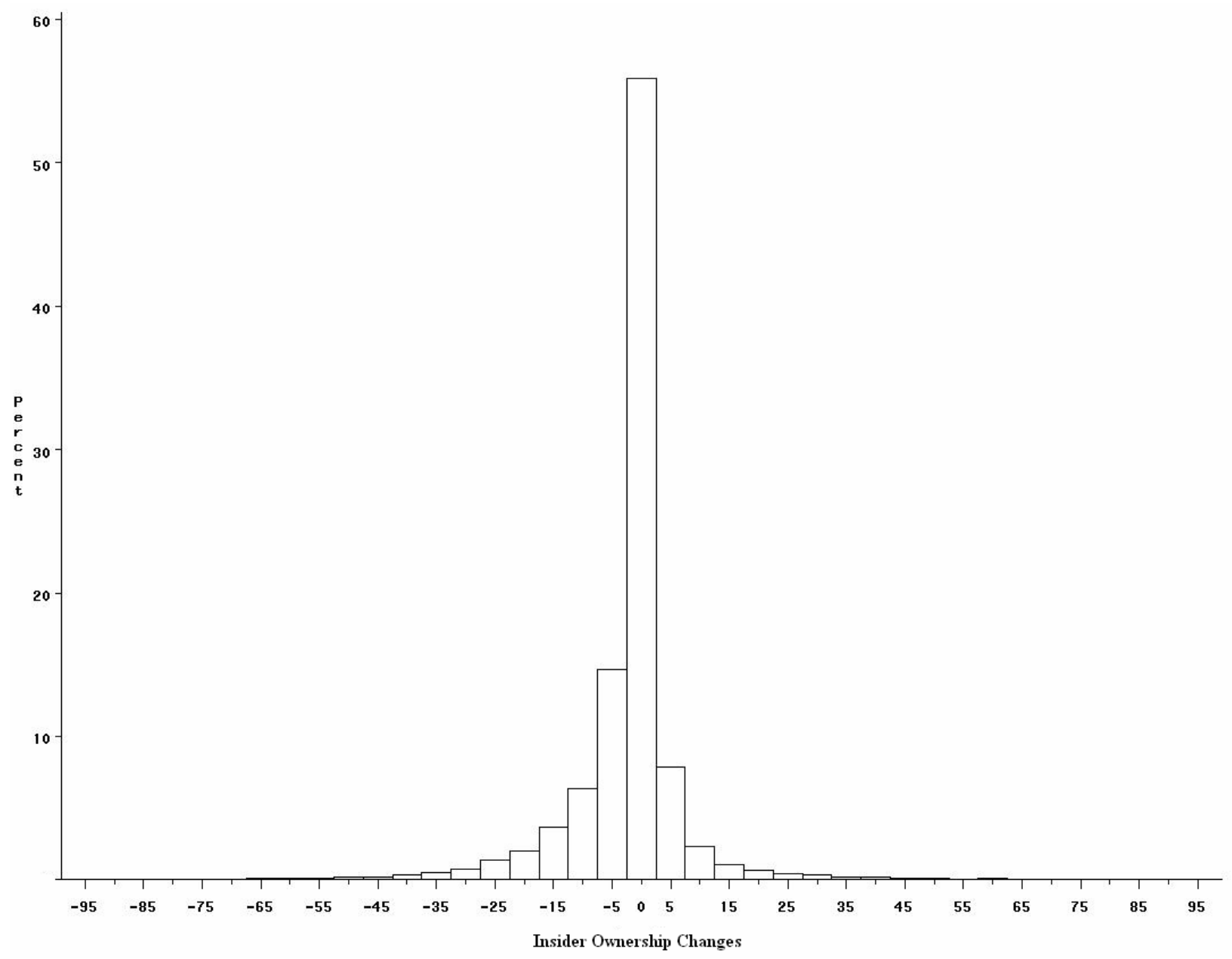

Figure 1: Distribution of the percentage annual insider ownership changes. The initial sample is from SDC Platinum and covers all firms that went public between 1970 and 2001, excluding unit offerings, rights offerings, reverse LBOs, spin-offs, utilities and financial firms. Insider ownership is sampled annually from Compact Disclosure over the 1986 - 2001. 

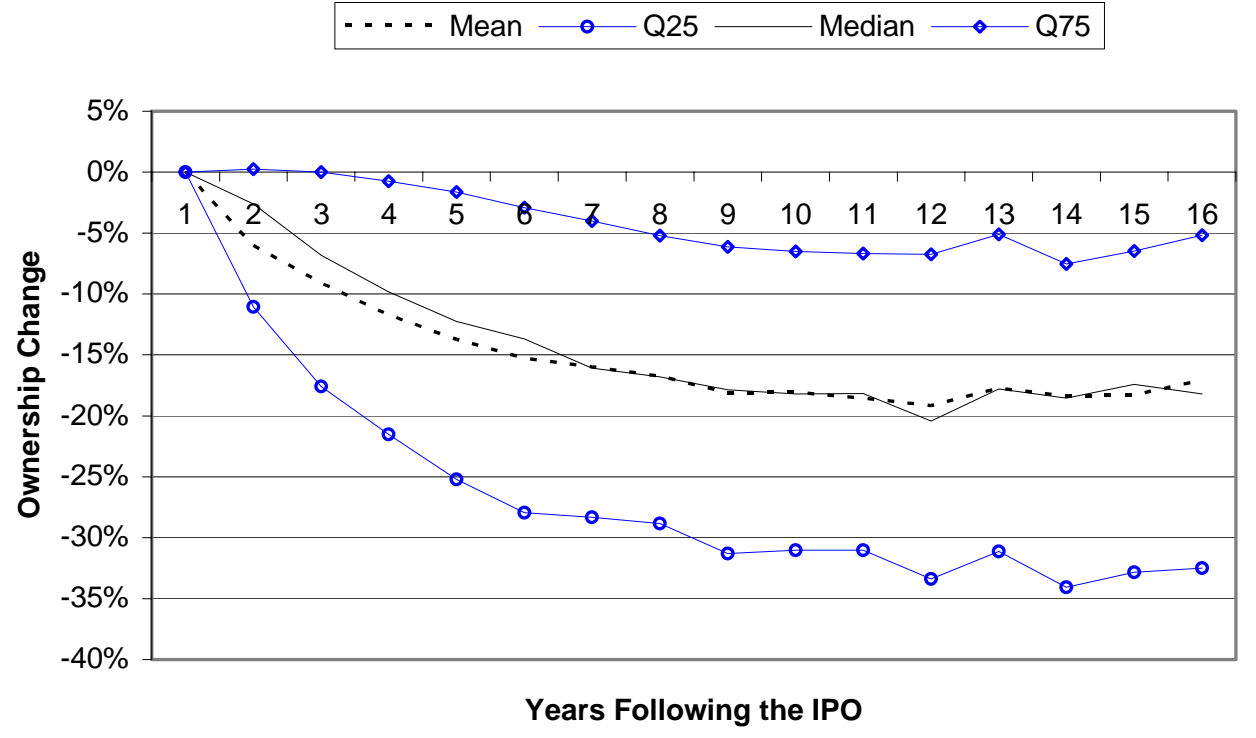

Figure 2: Distribution of Insider Ownership Changes Following an IPO. Distribution of insider ownership changes (current fraction minus initial fraction of insider ownership) in event time following an IPO. We exclude all firms that were widely held at the end of the first year following the IPO (insider ownership less than 10\%). The initial sample is from SDC Platinum and covers all firms that went public between 1986 and 2001, excluding unit offerings, rights offerings, reverse LBOs, spin-offs, utilities and financial firms. Insider ownership is sampled annually from Compact Disclosure over 1986 - 2001. 